\title{
Cenozoic basins in northern Taiwan and tectonic implications for the development of the eastern Asian continental margin
}

\author{
Ho-Shing $\mathrm{Yu}^{\mathrm{a}, *}$, Jinder Chow ${ }^{\mathrm{b}}$ \\ ${ }^{a}$ Marine Geology and Geophysics Division, Institute of Oceanography, National Taiwan University, Taipei, Taiwan, ROC \\ ${ }^{\mathrm{b}}$ Institute of Applied Marine Geophysics, National Taiwan Ocean University, Keelung, Taiwan, ROC
}

Received 4 March 1996; accepted 16 September 1996

\begin{abstract}
North of Taiwan, four offshore Tertiary basins extend seaward from the inner shelf of the East China Sea to the west of the Okinawa Trough. These basins are characterized by rifting features with NE-SW-trending half-grabens and fault blocks. Episodic rifting events have taken place from Paleocene to Early Miocene with the eastward shift of depositional centers. The Paleogene rift basins are filled primarily with lacustrine to shallow marine sediments, but also contain a slight amount of pyroclastics and basaltic flows. Regional subsidence has dominated during the late Tertiary and these Paleogene half-grabens have united into a large marginal sea basin overlain by a Neogene sedimentary wedge of shallow marine sediments. A fifth basin, the Paleogene Hsuehshan half-graben trough in present-day northern Taiwan has been deformed into mountain ranges by the collision of the Luzon Arc with the eastern Asian margin during the late Cenozoic Era.

The tectonic development of eastern Asian margin in northern Taiwan region has evolved into two phases. First, the eastward retreat of the West Pacific subduction zone and accompanied rifting of continental crust occurred during Late Cretaceous to Eocene times. Second, as the intensity of rifting decreased, thermal subsidence of eastern Asian margin prevailed and subsequently caused a tilting seaward continental margin on which a large marginal sea basin rests. Collision of the Luzon Arc with the eastern Asian margin in Taiwan deformed the Paleogene Hseuhshan Trough into mountain ranges (Late Miocene to present).(1) 1997 Elsevier Science B.V. All rights reserved.
\end{abstract}

Keywords: Basin; Taiwan; Stratigraphy; Structure; Tectonics

\section{Introduction}

Okada and Sakai (1993) presented the nature and development of late Mesozoic and early Cenozoic sedimentary basins in southwestern Japan and linked their origin to the tectonic development of the eastern Asian continental margin. The tectonic setting of these back-arc basins in

* Corresponding author. southwestern Japan being continuous with that of the East China Sea region was emphasized. Similarly, Paleogene basins exist in northern Taiwan (Teng et al., 1991) and Cenozoic basins are present in the neighboring offshore region (Sun, 1982). Knowledge of one aspect of basin history from one basin may facilitate a more thorough understanding of the basin history of the others. The nature and development of basins onland and off north Taiwan will definitely 
enchance the understanding of the tectonic development of the eastern Asian margin.

This study not only serves as the counterpart of a basin study in southwestern Japan (Okada and Sakai, 1993), but also compares the characteristics of basins in and around northern Taiwan with those in the East China Sea region and southwestern Japan. An attempt is also made to summarize and update the published literature of tectonicstratigraphic events recorded in the basins around northern Taiwan and correlate them with the tectonic history of eastern Asian continental margin. Moreover, tectonic models regarding the formation of these basins are examined to reveal the common tectonic aspects which are integrated into the tectonic development of the eastern Asian margin.

\section{Tectonic setting of Taiwan}

The island of Taiwan is located near the junction of the Ryukyu Arc and the Luzon Arc on the western margin of the Philippine Sea. It is the boundary between the Eurasian plate to the west and the Philippine Sea plate to the east (Fig. 1). Taiwan island can be divided into five major $\mathrm{N}-\mathrm{S}$ trending geologic units, named from east to west as follows: (1) Coastal Range; (2) Central Range; (3) Hsuehshan Range; (4) Western Foothills; and (5) Coastal Plain (Ho, 1986).

The Coastal Range is an accreted rock body to the island of Taiwan, representing the northern Luzon Arc colliding with the Asian continental margin beginning in the Pliocene (Suppe, 1984). The Central Range and Hsuehshan Range together are represented by a slate belt consisting of lower greenschist facies slates and sandstones. The Central Range comprises primarily Eocene and Miocene argillites and some interbedded sandstones. The Hsuehshan Range consists primarily of Eocene, Oligocene and Lower Miocene argillites and sandstones. The Lishan Fault is the boundary separating the Hsuehshan Range from the Central Range. West of the Hsuehshan Range lie the Western Foothills, consisting of more than ten kilometers of Cenozoic sediments. The less deformed Oligocene-Miocene sequences of the
Western Foothills comprise coastal to shallow marine sediments derived from the Asian continent. In contrast, the overlying PlioceneQuaternary strata consist of terrestrial to shallow marine sediments mainly from the rising mountain ranges to the east. The Coastal Plain is mainly covered by Quaternary alluvial sediments which reflect an uplifting of the Taiwan orogen and the accompanied foreland basin sedimentation (Covey, 1984).

\section{Deformed Paleogene basin in northern Taiwan}

Based on the reconstruction of the pre-deformation depositional environments for the upper Paleogene strata (Upper Eocene-Oligocene) in northern Taiwan, Teng et al. (1991) defined a Paleogene half-graben trough (Hsuehshan Trough) confined primarily by the coastal basement high (Kuanyin Uplift) to the west and the Central Range to the east (Fig. 2). Notably the Lishan Fault on the western flank of the Central Range functions as the boundary fault of the Paleogene half-graben. The trough's length was estimated to be at least $250 \mathrm{~km}$ long and about $200 \mathrm{~km}$ wide (Teng et al., 1991).

The sediments in the Hsuehshan Trough comprise mainly thick sequences ranging from Eocene to Miocene. Eocene coastal to outer shelf sediments overlie unconformably the Mesozoic basement. Thick shallow marine Oligocene sequences up to $2300 \mathrm{~m}$ thick rest on the Eocene sequences. The Paloegene (Eocene and Oligocene) sequences form a sedimentary wedge thickening eastward and toward the Lishan fault. In contrast, the younger coastal to shallow marine sediments have accumulated as flat-lying strata overlying the Paleogene wedge in the Miocene.

\section{Offshore Tertiary basins north of Taiwan}

Four Tertiary basins, separated by basement highs, occur in the offshore areas north of Taiwan (Fig. 3). They are the Tungyintao, North and South Pengchiahsu and Taiwan basins, extending from the East China Sea shelf seaward to the 


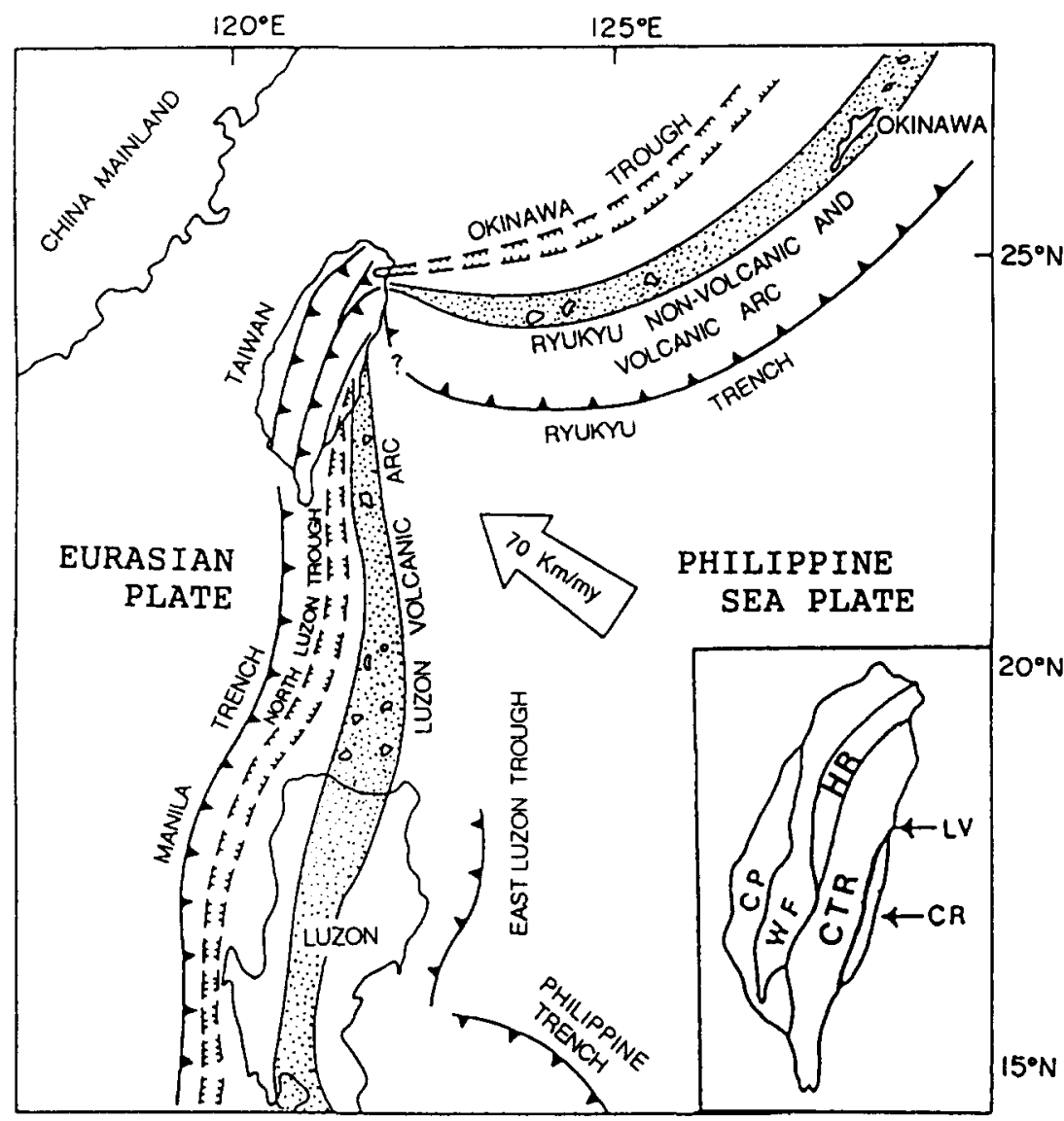

Fig. 1. Geological setting of Taiwan in the present time. The inset map shows five major N-S trending structural units of Taiwan (modified from Shyu and Chen, 1991). $C P=$ Coastal Plain; $W F=$ Western Foothills; $H R=$ Hsuehshan Range; $C T R=$ Central Range; $L V=$ Longitudinal Valley; $C R=$ Coastal Range.

Okinawa Trough. These basins are characterized by Paleogene sedimentary wedges overlain by flatlying Neogene sequences. A regional Upper Eocene/Lower Oligocene unconformity further separates these Tertiary basins into the Paleogene half-graben basins and Neogene subsidence basins (Sun, 1982; Yu, 1994).

The Tungyintao Basin, located underneath the inner East China Sea shelf, is floored by a preTertiary basement sloping seaward from the ZheMin Uplift to the Tungyintao Ridge (Lee, 1987; Hsiao et al., 1991; Yu, 1992) as shown in Figs. 3 and 4 . The pre-Tertiary basement is unconformably overlain by shallow marine Upper Paleocene sediments. Lower Tertiary (Paleocene, Eocene and Oligocene) lacustrine and shallow marine sedi- ments have filled in the half-graben and have also formed a sedimentary wedge thickening eastward and towards the Tungyintao Ridge. The early Tertiary half-graben in turn was completely covered by the flat-lying shallow marine deposits during the period from the Miocene to the Quaternary.

East of the Tungyintao Basin lie the North and South Pengchiahsu basins which are separated by the Pengchiahsu Platform (Fig. 3). Thick Paleocene and Eocene sediments have accumulated over the faulted pre-Tertiary basement (Sun, 1982). Paleocene sediments are characterized by volcaniclastics and thin beds of limestones. Thick Eocene mudstones interbedded with sandstones were widespread. Similar to the Tungyintao Basin, 


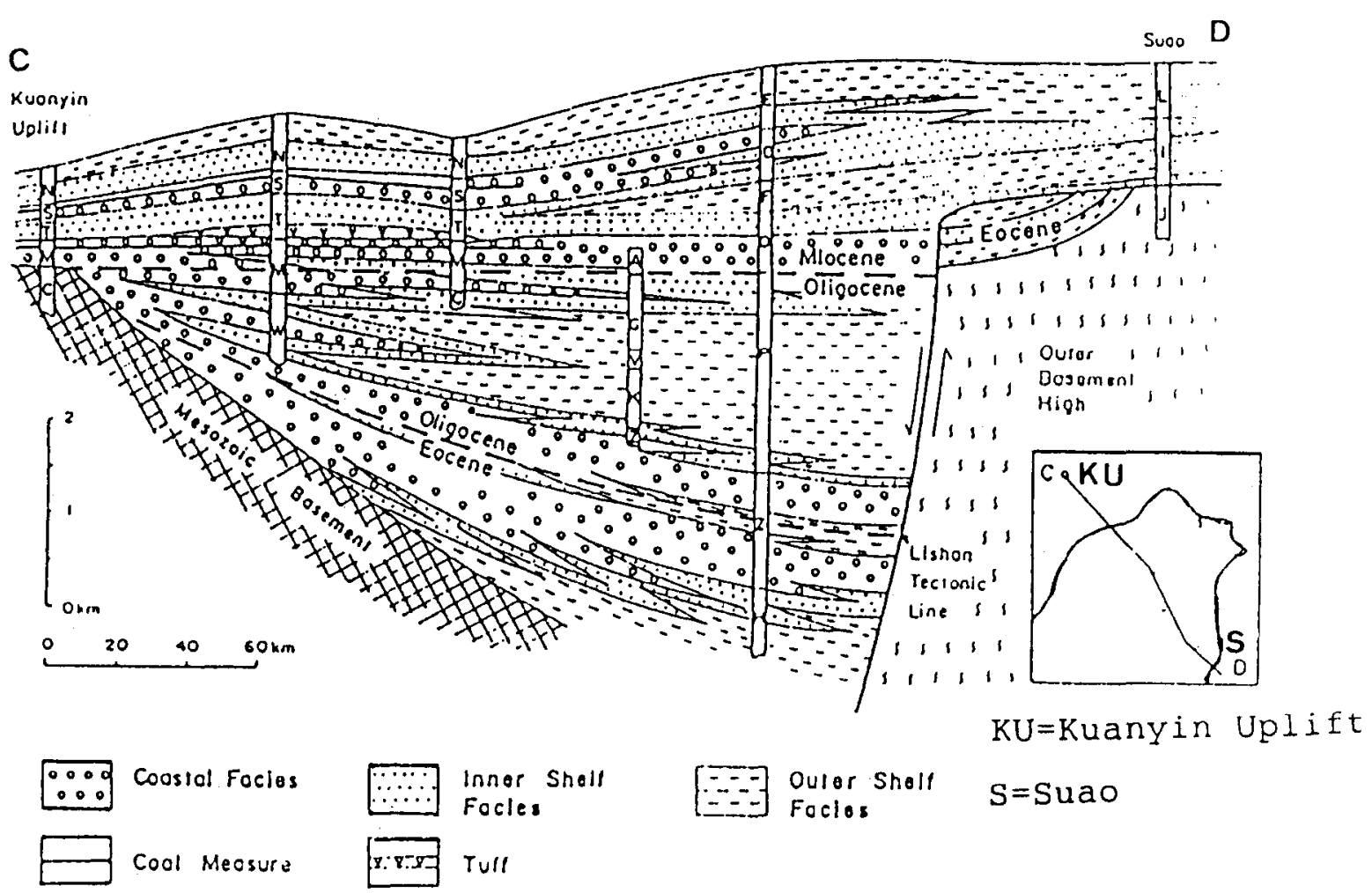

Fig. 2. Cross section of the Hsuehshan Trough showing a typical half-graben morphology. Note that the Paleogene sedimentary wedge thickens eastward and towards the Lishan boundary fault (after Teng et al., 1991).

the Paleogene sequences in the North and South Pengchiahsu basins also formed sedimentary wedges confined in the half-grabens (Fig. 4). Flatlying Oligocene to Quaternary sequences formed a platform of shallow marine sediments overlying the Paleogene half-grabens.

East of the North and South Pengchiahsu basins, the Taiwan Basin is bordered to the east by the Taiwan--Sinzi Folded Zone and to the west by the North Taiwan Ridge and Pengchiahsu Platform (Fig. 3). Pre-rift Upper Eocene strata are characterized by mudstones interbedded with some thin coal seams (Sun. 1982; Yu and Chi, 1992). The thickest Oligocene rilt sediments, mostly confined by paleohighs within the Taiwan - Sinzi Zone, are more than $4 \mathrm{~km}$ thick (Huang et al., 1992). During the late Tertiary and Quaternary coastal to open marine sediments formed a blanket covering the entire Taiwan Basin.

\section{Stratigraphy, structure and tectonic history}

The Tertiary basins onland and offshore northern Taiwan share common aspects in stratigraphy, structure and tectonic history. Fig. 5 summarizes the general stratigraphy and tectonic history of the basins of Tungyintao. North and South Pengchiahsu and Taiwan. The strata of these basins are commonly separated by three major unconformities, Lower Oligocene, Middle Miocene and Upper Pliocene, respectively. The pre-Tertiary basements of these basins include sedimentary. metamorphic and igneous rocks with ages ranging from pre-Cambrian to Cretaccous (Qin et al.. 1987).

We include below a general description of the Cenozoic stratigraphy and depositional environments of the sediments in the offshore basins north of Taiwan. This information comes mainly from 


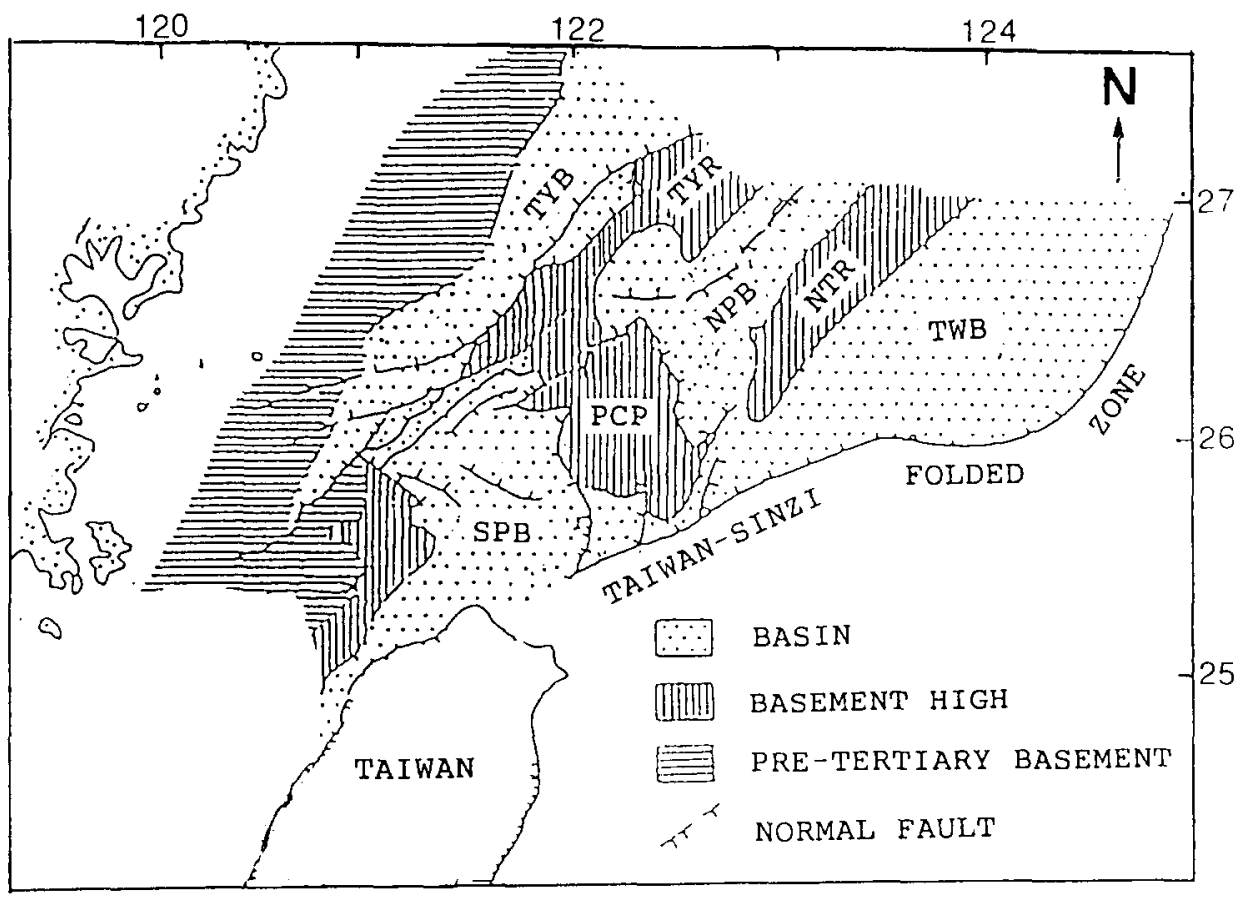

Fig. 3. The distribution of offshore Tertiary basins north of Taiwan. Note that these basins are NE-SW trending and separated by adjacent structural highs (after Sun, 1982). $T Y B=$ Tungyintao Basin; $T Y R=$ Tungyintao Ridge; $N P B=$ North Pengchiahsu Basin; $P C P=$ Pengchiahsu Platform: $S P B=$ South Pengchiahsu Basin; $N T R=$ North Taiwan Ridge; $T W B=$ Taiwan Basin.

Huang (1982), Sun (1982), Lee (1987), Liu (1989), Zhou et al. (1989), Lun (1992), Peng (1992), Yu and Chi (1992) and Zhao and Ren (1996). The principal database for the above studies of depositional environments and sedimentary facies are sets of seismic reflection profiles and exploration wells. The spatial and temporal variations of the majaor sedimentary facies in the eastern Asian margin west and north of Taiwan are shown in Fig. 6.

The Paleocene strata were deposited in lacustrine to shallow marine enviromments and were dominated by mudstones interbedded with sandstones. Locally, limestones and tuffaceous rocks are also present. The Paleocene strata can be divided into a Lower Paleocene and a Upper Paleocene unit. The Lower Paleocene sediments were mainly deposited in non-marine environments. The Upper Paleocene sediments were characterized by transgressive shallow marine facies with nannofossil zones of NP5 to NP9. The thickness of Paleocene sequences is about $2000 \mathrm{~m}$. The Paleocene marine facies is mainly distributed in the eastern Asian margin north of Taiwan (Fig. 6A). Note that the sea transgressed from southeast with marine sediments overlying the basement highs. A regressive stage began in the Early Eocene. Thick (up to $4000 \mathrm{~m}$ ) shaly Eocene strata were deposited in fluvial-coastal environments, locally including shallow marine deposition. Several beds of bioclastic limestones contain nannofossils belonging to NP13-NP18 zones. Volcaniclastics and tuffaceous sediments are also present. Fig. $6 \mathrm{~B}$ shows that the Eocene fluvial-coastal facies extended along the shallow shelf of the eastern Asian margin. The basement highs were completely overlain by Eocene sequences and the adjacent basins continued to subside and received thick Eocene sediments.

During the Early Oligocene a widespread regression occurred and resulted in a major unconformity separating the Paleogene (Paleocene-Eocene) from the overlying younger strata (Upper Oligocene-Miocene). The strata of the Oligocene 

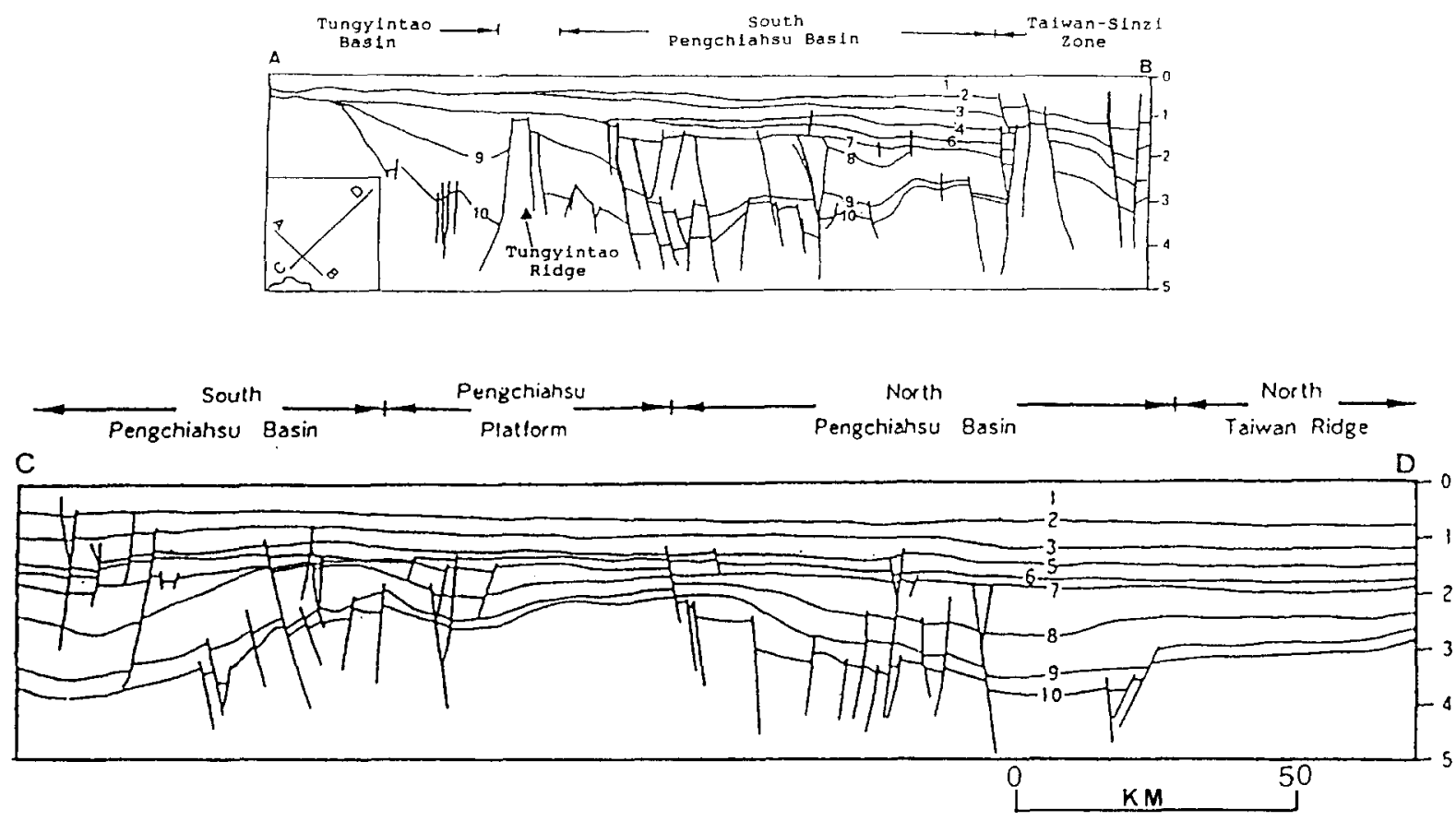

Fig. 4. Dip and strike profiles across the East China Sea shelf near Taiwan exhibit the typical rifting features of high-angle normal faults and half-grabens. Individual basins are separated by uplifted blocks. After Sun (1982) and Huang et al. (1992). $I=$ Pleistocene; $2=$ top of Pliocene; $3=$ top of M. Miocene; $4=$ base of M. Miocene; $5=$ top of Mushan Formation (NNI); $6=$ top of Oligocene; $7=\mathrm{O}$ horizon (Oligocene): $8=$ top of Eocene: $9=$ top of Paleocene; $10=$ top of Cretaceous. Both profiles are shown by a same horizontal scale.

consist mainly of sandstones, mudstones with intercalations of carbonate layers and coal seams, reflecting fluvial to coastal environments. Erosion and non-deposition prevailed during the Oligocene and resulted in a decrease of areal extent of Oligocene sediments. The thickness of Oligocene sequences is generally less than $1000 \mathrm{~m}$. The Oligocene fluvial-coastal facies is distributed as a narrow belt along the eastern Asian margin (Fig. 6C).

The Miocene strata are characterized by cyclic sediments ranging from non-marine (lacustrine and flood plain) to shallow marine facies. The Miocene sediments consist mainly of alternating mudstones and sandstones with intercalations of coal seams and marine beds, reflecting high frequency of fluctuations of sea levels. A major unconformity occurred in the Middle Miocene with varying degrees of erosion or non-deposition among these basins. The Upper Miocene sequence commonly contains basaltic extrusions, indicating eastern Asian continental margin rifting. The thickness of Miocene strata is about $2000 \mathrm{~m}$. The areal extent of Miocene deposition increased substantially and the fluvial-coastal facies reached as far as the present-day Ryukyu Islands (Fig. 6D). In contrast, Pliocene sediments, consisting mainly of sandstone and mustones, were deposited during the shallow marine transgression phase, resulting in a sedimentary wedge of sands and muds on the eastern Asian continental shelf. The Pliocene shallow marine sedimentation has prevailed over the entire East China Sea (Fig. 6E). Note that the Taiwan orogen began to rise above the sea level in the Early Pliocene and received little sediments. The shallow marine sedimentation continued to dominate in the Quaternary and resulted in a blanket of sands and muds draping over the entire East China Sea.

In general, Paleogene and Neogene sequences in these basins are separated by a regional Upper Eocene/Lower Oligocene unconformity. Paleogene 


\begin{tabular}{|c|c|c|c|c|c|c|}
\hline \multicolumn{2}{|c|}{ Age $\quad$ Basin } & Tungyintao & Hsuehshan & $\begin{array}{c}\text { North and South } \\
\text { Pengchiahsu }\end{array}$ & Taiwan & $\begin{array}{l}\text { Regional } \\
\text { Tectonics }\end{array}$ \\
\hline \multirow[b]{2}{*}{ Pleistocene } & Late & \multirow{2}{*}{$\begin{array}{l}\text { Mudstones } \\
\text { Sandstones }\end{array}$} & & \multirow{2}{*}{$\begin{array}{l}\text { Mudstones } \\
\text { Sandstones } \\
\end{array}$} & \multirow{2}{*}{$\begin{array}{c}\text { Mudstones } \\
\text { NN19-NN21 }\end{array}$} & \multirow{5}{*}{$\begin{array}{l}\text { Penglat } \\
\text { Movement }\end{array}$} \\
\hline & Early & & & & & \\
\hline \multirow{2}{*}{ Pliocene } & Late & Mudstones & & Mudstones & Mudstones & \\
\hline & Early & Sandstones & & Sandstones & Sandstones & \\
\hline \multirow[b]{3}{*}{ Miocene } & Late & \multirow{3}{*}{$\begin{array}{l}\text { Mudstones } \\
\text { Sandstones } \\
\text { Pyroclastics }\end{array}$} & & \multirow{3}{*}{$\begin{array}{l}\text { Mudstones } \\
\text { Sundstones } \\
\text { Lava Flows } \\
\text { Tuffs }\end{array}$} & & \\
\hline & Middle & & & & Mudstones & Longjing \\
\hline & Early & & $\begin{array}{l}\text { Sandstones } \\
\text { Shales } \\
\text { Tuffs }\end{array}$ & & $\begin{array}{l}\text { Sandstones } \\
\text { Coal Seams } \\
\text { Mudstones } \\
\text { Sandstones }\end{array}$ & Movement \\
\hline \multirow[t]{2}{*}{ Oligocene } & Late & & Shales & $\begin{array}{l}\text { Sandstones } \\
\text { Mudstones }\end{array}$ & $\begin{array}{l}\text { Coal Seams } \\
\text { Mudstones } \\
\text { Sandstones }\end{array}$ & \multirow{2}{*}{$\begin{array}{c}\text { Puli } \\
\text { (Yuquan) } \\
\text { Movement }\end{array}$} \\
\hline & Early & & & & Limestones & \\
\hline \multirow[t]{2}{*}{ Eocene } & Late & & $\begin{array}{l}\text { Sandstones } \\
\text { Shales }\end{array}$ & & $\begin{array}{l}\text { Sandstones } \\
\text { Mudstones } \\
\text { Coal Seams } \\
\text { NP16-NP18 }\end{array}$ & \multirow{4}{*}{$\begin{array}{c}\text { Shuanchi } \\
\text { (Qujiang) } \\
\text { Movement } \\
\text { Taiping } \\
\text { (Yandang) } \\
\text { Movement }\end{array}$} \\
\hline & Early & Shales & & $\begin{array}{l}\text { Mudslones } \\
\text { Sandstones }\end{array}$ & & \\
\hline Paleocene & & $\begin{array}{l}\text { Coal Seams } \\
\text { Mudstones } \\
\text { Sandstones } \\
\text { Pyroclastics }\end{array}$ & & & & \\
\hline Cretaceous & & $\begin{array}{l}\text { Sandstones } \\
\text { Pyroclastics }\end{array}$ & $\begin{array}{l}\text { Shallow } \\
\text { Marine } \\
\text { Clastics }\end{array}$ & & & \\
\hline
\end{tabular}

Fig. 5. Summary of the stratigraphy and tectonic history of the offshore Cenozic basins north of Taiwan (modified from Huang et al., 1992). Note that three major unconformities are associated with Puli, Longjing and Penghai movements, respectively.

sediments are commonly faulted non-marine to marine facies deposited in the half-graben. Neogene strata exhibit generally parallel, flat-lying layers of coastal to open marine facies overlying these infilled half-grabens.

The Paleogene half-graben, such as the Tungyintao Basin, located in the inner shelf is mainly filled with Paleocene and Eocene sediments whereas the Paleogene basin, such as the Hsuehshan Trough, situated in the outer shelf, is mainly filled with Upper Eocene and Oligocene sequences (Huang et al., 1992; Teng, 1992). The relationships between the age of the basin fills and basin locations suggest a progressively decreasing age from the inner to outer shelf. Teng (1992) further grouped these basins into inner and outer shelf troughs, respectively. Furthermore, Huang et al. (1992) pointed out that the rifting stages of the basins of Tungyintao, North and South Pengchiahsu and Taiwan are mainly in the Paleocene, Eocene and Oligocene, respectively. For these offshore basins north of Taiwan, the rifting centers migrated progressively from coastal to deep-water areas with decreasing age.

Tectonically, the Hsuehshan Trough can be considered one of the Paleogene troughs (half-graben) in the eastern China continental shelf during the early Tertiary until it was deformed into the mountain ranges in northern Taiwan by the late Tertiary and Quaternary collisional orogeny. These basins characterize the eastern Asian margin which has been known to be a rift margin since the Late 

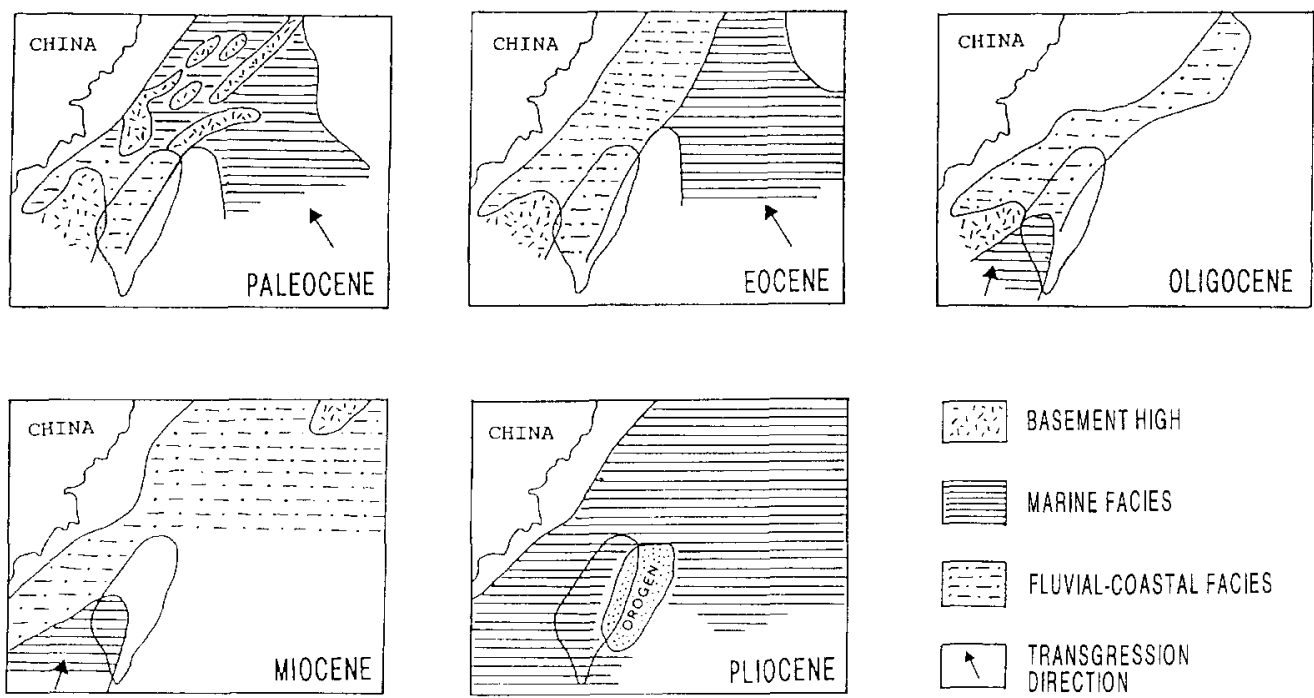

Fig. 6. The distribution of major sedimentary facies in the eastern Asian margin west and north of Taiwan during the Tertiary. Modified from Liu (1989) and Yu and Chi (1992).

Cretaceous ( $\mathrm{Li}, 1984$; Wang, 1987; Sun and Hsu, 1991). This rift margin is characterized by a mosaic of NE-SW-trending fault-bounded basins and accompanied by uplited and tilted basement blocks (graben and horsts). In terms of continental rifting, the rock sequences of these basins can be divided into pre-rift, syn-rift and post-rift sequences in an order of decreasing age.

\section{Tectonic models}

Although the rifting nature of the eastern Asian continental margin in the Taiwan region has been recognized, the consensus of the tectonic development of these basins around Taiwan has not been reached. Four major tectonic models are briefly summarized in the following.

\subsection{Relict back-arc hasin model}

Huang et al. (1992) emphasized the observations of the regularity in age variations in both the prerift sequences and syn-rift sequences of the basins off northern Taiwan and related their origin to a series of relict back-arc basin extension. The basement highs of the Tungyintao Ridge, Pengchiahsu
Platform and North Taiwan Ridge (Fig. 3) were considered to be relict volcanic island ares. The rifting basins of Tungyintao, Pengchiahsu and Taiwan alternating with these relict ares are relict back-arc basins progressively with a decreasing age of rifting. A weakness for this model is that no geochemical or petrological evidence supports the uplifted fault blocks such as Tungyintao Ridge being of volcanic origin. This model simply follows the hypothesis of the formation of relict back arc basins (Hsü, 1988).

\subsection{Two-stage continental stretching and rifting model}

On the basis of stratigraphic variations and spatial distribution of the rifting basins at the eastern Asian margin, Teng (1992) suggested that there are two major stages of rifting: one is in the Paleocene and Early Eocene and the other is in the Late Eocene and Oligocene. The early Paleogene rifting caused the formation of inner troughs located in the inner shelf near mainland China whereas the late Paleogene rifting has formed the outer troughs situated in the outer shelf areas. This model shows that the rifting centers in eastern Asian margin migrated pro- 
gressively eastward with decreasing age. However, this model assumes that the crust underneath the eastern Asian margin has been stretched and thinned before rifting without providing thermal and mechanical properties of the crust. Therefore, the statement of two-stage stretching and rifting in the region of eastern Asian margin is inconclusive.

\subsection{Extensional tectonics and hot spot model}

Based on the seismic profiles and well data in Taiwan region from the petroleum industries, Sun and Hsu (1991) suggested that the continental margin north of Taiwan has been dominated by extensional tectonics from the Late Cretaceous to Miocene. Sedimentary basins onland and off Taiwan have been formed by rifting during the early Tertiary and by subsidence during the late Tertiary and Quaternary. Accompanying the extensional tectonics in the margin, intense volcanic activities have produced widespread lava flows and pyroclastics which have accumulated in the basins and adjacent basement highs. Volcanism occurred primarily in four stages: Late Paleocene, Eocene, Late Miocene and Pliocene. Except for the Pliocene volcanism which is related to the rifting and spreading of the southern Okinawa Trough near northeastern Taiwan, the rest of the volcanic rocks are related to the fractures due to continental rifting in the margin. Sun and $\mathrm{Hsu}$ (1991) further suggested that the widespread volcanism may be related to the hot spots beneath eastern Asian continental margin. The hot spots may cause the crust to stretch and rift, resulting in the formation fractures as conduits for the Tertiary lava flows. However, no direct evidence suggests the existence of the hot spots proposed by Sun and Hsu (1991).

\subsection{Shear-extensional tectonics model}

Yu ( 1989 ) proposed the shear-extensional model for the development of the eastern Asian margin. During Jurassic-Early Cretaceous times, the eastern Asian margin experienced NE-SW-trending shear stress due to the Izanagi plate subducting underneath the Eurasian plate. From the Late
Cretaceous to the Late Eocene, rifting of the attenuated continental crust along the pre-existing NE-SW-trending faults developed rift basins in the present-day East China Sea shelf. This models summarizes the geological essentials of the MesoCenozoic basins in eastern China and emphasizes the role of shear stress accompanied with crust rifting. Again, this model provides no data of the crustal properties.

These different tectonic models for development of the basins in eastern Asian margin account for various geologic and geophysical observations, although discrepancies exist. The principal database for the tectonic studies of the offshore basins north of Taiwan are sets of seismic reflection profiles and exploration wells. Although seismic stratigraphy analysis and structural interpretations from these profiles and well data currently provide various tectonic models of the eastern Asian continental margin, limitations exist in the understanding of the mechanism of continental margin rifting because of the lack of data related to thermal and mechanical properties of the crust and lithosphere in eastern Asian margin.

The Neogene extensional Tainan Basin off southwestern Taiwan is characterized by asymmetrical extensional structures. Yang et al. (1991) suggested a simple shear model of Wernicke (1985) for the development of the Tainan Basin. In addition, Zhou et al. (1995) recognized the asymmetric development of rift structures in the northern and southern South China Sea margins, and proposed a simple shear model (Wernicke, 1981) for the tectonic development of the South China Sea margins. Therefore, the simple shear model may be applicable to the eastern Asian margin.

This paper calls for attention to the important role of the crustal structure in rifting margins. Although the detailed crustal structure in eastern Asian margin (East China Sea region) is not well demonstrated, the structure of crust north of the South China Sea (Yao et al., 1994) may be applicable to that in eastern Asian margin. The crust thins from $26-28 \mathrm{~km}$ in a continental shelf to 5-7 km (oceanic crust) in the South China Sea Basin. The thinning of the crust exhibits a stepdown or terrace-like pattern rather than the pattern of a smooth curve. Yao et al. (1994) suggested 
that four episodes of rifting have taken place from the Late Cretaceous to the Quaternary in the northern margin of the South China Sea.

On the other hand, the crust in East China Sea region thins from $28-30 \mathrm{~km}$ in continental shelf to $17-20 \mathrm{~km}$ in the Okinawa Trough (Qin et al., 1987). The variations of the crustal thickness clearly suggest that the crust in the eastern Asian margin has been attenuated less intensely that that in the South China Sea continental margin. Without the profiles of seismic velocity plotted against the depth of the crust, the detailed crustal structure beneath the East China Sea shelf can not be depicted as that in the northern margin of the South China Sea (Yao et al., 1994). Hence, the potential episodes of rifting in eastern Asian margin can not be deduced from the crustal thickness alone.

\section{Tectonic evolution}

The tectonic aspects of these Tertiary rift basins in and around northern Taiwan can be integrated into the tectonic evolution of the East China Sea region, although the thermal and mechanical properties of the crust and lithosphere are not available. Fig. 7 presents the schematic diagrams of the distribution of the basins in eastern Asian margin in time and space.

In eastern China, the locus of successive subduction-related Mesozoic-Cenozoic magmatic arc migrated from inland to coastal areas (Zheng, 1985). A similar shift is also reported in South China Sea margin where onland Lower Cretaceous granitic rocks in Guangdong Province changed progressively seaward to Upper Cretaceous-Lower Eocene magmatic rocks in the offshore areas. Late Cretaceous magmatism occurred extensively in southwestwern Japan and South Korea (Letouzey et al., 1989). Eastward shifting of the magmatic arc suggests that the eastward retreat of the West Pacific subduction zone in the Late Cretaceous caused extensive rifting in the areas of the presentday East China Sea shelf and developed a series of NE-SW-trending Paleocene-Early Eocene halfgrabens (Fig. 7A). Intense rifting continued into Eocene and produced a series of NE-SW-trending extensional faults and half-grabens. The Eocene extension may be related to changes in plateconvergence rates along the eastern Asian margins (Northrup et al., 1995). During the Oligocene and Early Miocene period, the rifting continued and the basins received up to $5,000 \mathrm{~m}$ thickness of sediments, e.g., the Taiwan Basin (Sun, 1982). In nothern Taiwan, the Oligocene sediments more than $2 \mathrm{~km}$ thick were extended as far as western Central Range and deposited in the Hsuehshan Trough (Teng et al., 1991). However, during the Early Oligocene to Early Miocene the northern region of Taiwan underwent widespread denudation with the erosion of the Upper Eocene strata from structurally high areas. Oligocene sediments were restricted to the deep depositional centers (Fig. 7B). During the Late Miocene through Quaternary, the subduction of the NW-dipping Philippine Sea plate underneath the eastern Chinese margin, the back-arc opening of the Okinawa Trough and the collision between the northern Luzon Arc with the eastern Chinese margin played the important roles in the developmemt of the region. The eastern Asian margin was dominated by regional subsidence and subsequently caused a large unified marginal sea basin, including the basins of Tungyintao, North and South Pengchiaohsu and Taiwan, in the East China Sea shelf. In contrast, the Paleogene Hsuehshan trough in the present-day northern Taiwan was deformed into mountain ranges by the colliding of the Luzon arc with the eastern Asian margin (Fig. 7C and D).

\section{Conclusions}

The Late Cretaceous-Paleocene basins north of Taiwan bear half-graben structures that are similar to those of the Inner Zone of southwestern Japan, which are closely related to the subduction of Kula plate and later eastward retreat of the West Pacific plate along the eastern Asian margin. The development of the Eocene-Oligocene rift basins north of Taiwan was influenced not only by inherited NE-trending rifting but also by NW-SEdirected strike-slip movements. During the Late Miocene-Recent southwestern Japan converged 

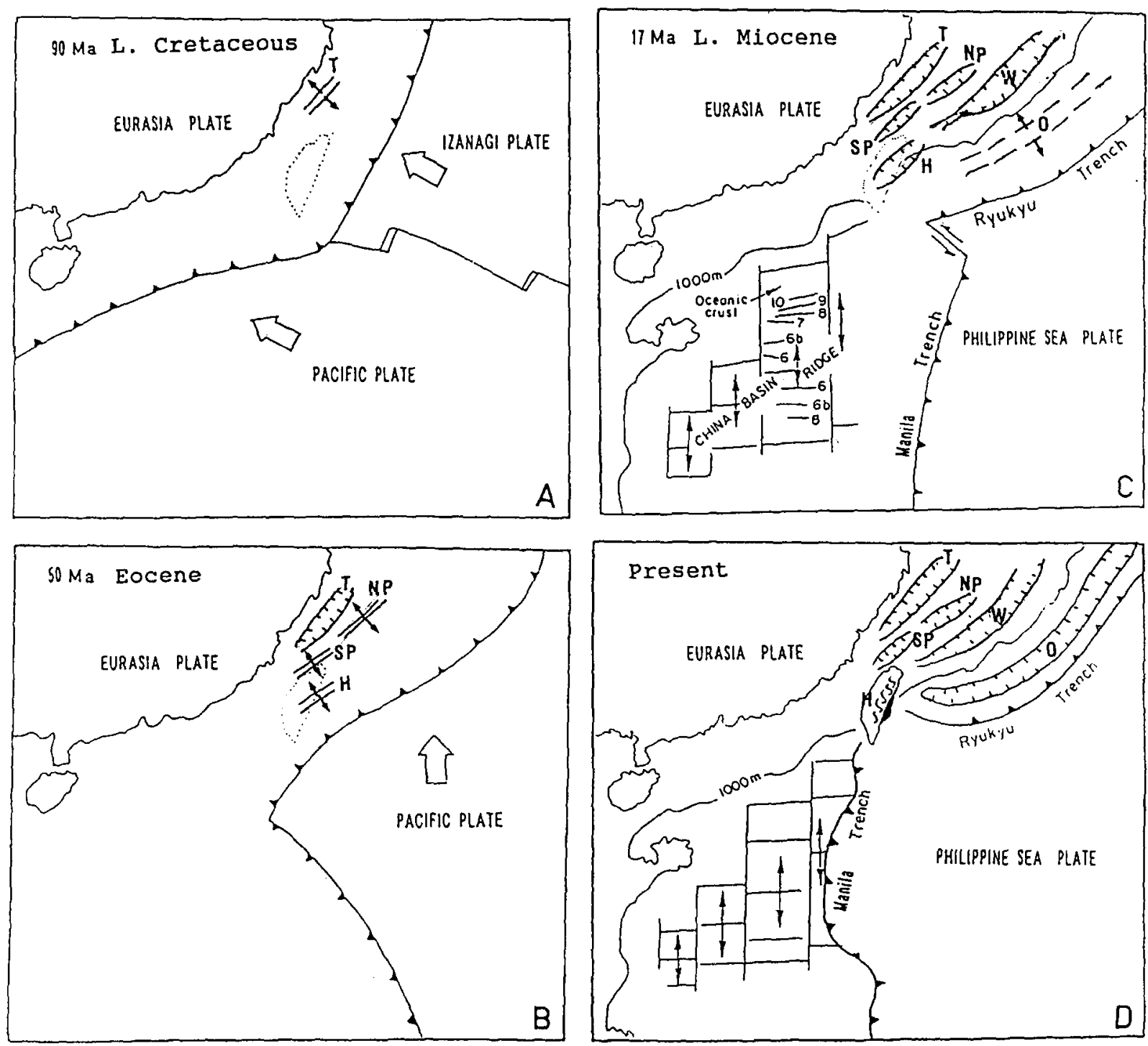

Fig. 7. The tectonic evolution in the eastern Asian margin. The eastward retreat of the West Pacific subduction zone during the Late Cretaceous caused extensive rifting of the crust and formed many NE-SW trending Paleocene basins (A). Intense rifting continued into Eocene and produced a series NE-SW-trending extensional fault and half grabens (B). During the Late Miocene to Quaternary the subduction of Philippine Sea plate under the East China Sea margin, the opening of Okinawa Trough and the collision between the Luzon Arc and eastern Asian margin in Taiwan are key factors in the tectonic development in the region (C and D). Modified from Teng (1992) and Yu and Chi (1992). $T=$ Tungyintao Basin; NP=North Pengchiahsu Basin; $S P=$ South Pengchiahsu Basin; $H=$ Hsuehshan Trough; $W=$ Taiwan Basin; $O=$ Okinawa Trough.

with the westward moving Philippine Sea plate while the eastern Asian margin north of Taiwan experienced regional subsidence behind the Okinawa Trough (back-arc basin) to subsequently form a large marginal sea basin.

\section{Acknowledgements}

Hakuyu Okada, Kyushu University, Japan and J.C. Chen, Institute of Oceanography, NTU, Taiwan critically reviewed the manuscript. 
Constructive comments and suggestions by two reviewers improved this manuscript greatly. This study was supported through grants from National Science Council, Taiwan, ROC.

\section{References}

Covey, M., 1984. Lithofacies analysis and basin reconstruction, Plio-Pleistocene western Taiwan foredeep. Pet. Geol. Taiwan, 20: 53-83.

Ho, C.S., 1986. Geology of Taiwan: Explanatory text of the geology map of Taiwan. Ministry of Economic Affair. Taiwan, $164 \mathrm{pp}$.

Hsiao, P.T., Lin, K.A., Lo, S.Z., Hsu, S.H., Chi, W.R. Huang, S.T., Shen, J.C., Chiu, J.H. and Wang, H.J., 1991. Petroleum appraisal on Tungyintao Basin. Pet. Geol. Taiwan, 26: $183-213$.

Hsü, K.J., 1988. Relict back-arc basins: Principles of recognition and possible new examples from China. In: K.L. Kleinspehn and C. Paola (Editors), New Perspectives In Basin Analysis. Springer, Berlin. pp. 245-263.

Huang, T.C., 1982. Tertiary calcareous nannofossil stratigraphy and sedimentation cycles in Taiwan. Proc. 2nd ASCOPE Conf., 1981, Manila, pp. 873-885.

Huang, S.T., Ting, H.H., Chen, R.C., Chi, W.R., Hu, C.C. and Shen, H.C., 1992. Basinal framework and tectonic evolution of offshore northern Taiwan. Pet. Geol. Taiwan. 27: 47-72.

Lee, T.Y., 1987. Seismic stratigraphy and tectonic evolution of Tungyintao Basin, offshore northern Taiwan. Master Thesis, Univ. Texas at Austin, TX, $106 \mathrm{pp}$.

Letouzey, J., Sage, L. and Muller, C., 1989. Geological and Structural Map of Eastern Asia. Introductory Notes. Am. Assoc. Pet. Geol., Tulsa, OK, 52 pp.

Li, D., 1984. Geologic evolution of petroliferous basins on continental shelf of China. Am. Assoc. Pet. Geol. Bull., 68: $993-1003$.

Liu, G., 1989. Geophysical and geological exploration and hydrocarbon prospects of the East China Sea. China Earth Sci., 1: 43-58.

Lun, Y.Q., 1992. Geotectonic framework of the East China Sea. In: J.S. Watkins et al. (Editors), Geology and Geophysics of Continental Margins. AAPG Mem., 53: 17-25.

Northrup, C.J., Royden, L.H. and Burchfiel, B.C., 1995. Motion of the Pacific plate relative to Eurasia and its potential relation to Cenozoic extension along the eastern margin of Eurasia. Geology, 23: 719- 722 .

Okada, H. and Sakai, T., 1993. Nature and development of Late Mesozoic and Early Cenozoic sedimentary basins in southwest Japan. Palaeogeogr., Palaeoclimatol., Palaeoecol. 105: 3-16.

Peng, S., 1992. Tertiary transgressive sequences and stratigraph ic correlation in China offshore area. Mar. Geol. Quat. Geol., 12: 41-56 (in Chinese).
Qin, Y.L., Zhao, Y. and Zhao, S., 1987. Geology of the East China Sea. Science Press, Beijing, 290 pp. (in Chinese).

Shyu, C.T. and Chen, S.C., 1991. A topographic and magnetic analysis off southeastern Taiwan. Acta Oceanogr. Taiwan., 27( I): 20 .

Sun, S.C., 1982. The Tertiary basins of offshore Taiwan. Proc. 2nd ASCOPE Conf., 1981, Manila, pp. 125 135.

Sun, S.C. and Hsu, Y.Y., 1991. Overview of the Cenozoic geology and tectonic development of offshore and onshore Taiwan. TAICRUST Proc., Taipei, Taiwan, pp. 35-47.

Suppe, J., 1984. Kinematics of arc-continent collision. flipping of subduction, and back-are spreading near Taiwan. Mem. Geol. Soc. China, 6: 21-34.

Teng, L.S., 1992. Geotectonic evolution of Tertiary continental margin basins of Taiwan. Pet. Geol. Taiwan, 27: $1 \cdots 19$.

Teng, L.S., Wang, Y., Tang, C.H., Huang. C.Y.. Huang. T.C., Yu. M.S. and Ke, A., 1991. Tectonic aspects of the Paleogene depositional basin of northern Taiwan. Proc. Geol. Soc. China, 34: 313-336.

Wang, Y., 1987. Continental margin rifting and Cenozoic tectonics around Taiwan. Mem. Geol. Soc. China, 9: 227-240.

Wernicke, B., 1981. Low-angle normal faults in the Basin and Range Province: Nappe tectonics in an extending orogen. Nature, 291: 645-648.

Wernicke, B.. 1985. Uniform-sense normal simple shear of the continental lithosphere. Can. J. Earth Sci., 22: 108-125.

Yang, K.M., Ting, H.H. and Yuan, J., 1991. Structural styles and tectonic modes of Neogene extensional tectonics in southwestern Taiwan: Implications for hydrocarbon exploration. Pet. Geol. Taiwan, 26: 1-31.

Yao, B.C., Zeng, W.J., Chen, Y.Z., Zhang, X.L., Hayes, D.E., Diebold, J., Buhl, P. and Spangler, S., 1994. The crustal structure in the eastern part of the northern margin of the South Chind Sea. Acta Geophys. Sin.. 37: 27-35.

Yu, H.S., 1989. East China Sea Basin--.. It geologic framework and tectonic history. Acta Oceanogr. Taiwan., 24: 2338.

Yu, H.S., 1992. Geology of the Tungyintao basin off northwestern Taiwan. Acta Oceanogr. Taiwan, 28: 31-45.

Yu, H.S., 1994. Structure, stratigraphy and basin subsidence of Tertiary basins along the Chinese southeastern continental margin. Tectonophysics, 235: 6376.

Yu, H.S. and Chi, W.R., 1992. Geology of the Taiwan basin off northeastern Taiwan-An overview. Pet. Geol. Taiwan, 27: 73-88.

Zhao. J. and Ren, J., 1996. Relations of Cenozoic geologic framework to oil and gas exploration in East China Sea. Mar. Geol. Quat. Geol., 16: 43-46 (in Chinese).

Zheng, X., 1985. Meso-Cenozoic voleanic rocks in East China and adjacent areas with relation to plate tectonics. Tectonics, 112: $533-550$.

Zhou, D., Ru, K. and Chen, H.Z., 1995. Kinematics of Cenozoic extension on the South China Sea continental margin and its implications for the tectonic evolution of the region. Tectonophysics, 251: 161-177.

Zhou, Z., Zhou, J. and Yin, P., 1989. Characteristics and tectonic evolution of the East China Sea. In: X. Zhu (Editor), Chinese Sedimentary Basins. Elsevier, Amsterdam, pp. 165-179. 